\title{
Marsela Musabelliu
}

Xiamen University

http://dx.doi.org/10.18778/8142-287-1.07

\section{The Man with a Dream and a Plan: $X i$ Jinping, the "Chinese Dream" and the Belt and Road Initiative}

\begin{abstract}
The purpose of this paper is to seek the organizing principle of China's Belt and Road Initiative in terms of the People's Republic of China's overall foreign policy objectives, and, in order to do this, an understanding of the leadership of the Middle Kingdom becomes imperative. There are five generations of Chinese leaders since the proclamation of the PRC and obviously each of them has had distinct attitudes when it comes to foreign policy and the decision making process, since their actions have been the outcome of specific historical, social and geopolitical conditions.

Notwithstanding, we see a continuity of grand strategies and application of the same principles of Socialism with Chinese Characteristics, inherited from one establishment by the other. The current leader Xi Jinping, soon after getting to be General Secretary of the Communist Party in late 2012, expressed what might turn into the hallmark of his administration: "The Chinese Dream - the great rejuvenation of the Chinese nation." Some months later the New Silk Road Strategy was proclaimed; the proposed revival of a great trade route which, two thousand years ago, bridged Eastern and Western cultures across the Eurasian continent, becomes in the 21st century the fulcrum of the Belt and Road Initiative and the blueprint of the actual Chinese foreign policy.
\end{abstract}

Keywords: "Chinese Dream," Xi Jinping, reforms, Belt and Road Initiative 


\section{Introduction}

Fukuyama (2013) believes that the first modern state is unambiguously the Qin dynasty founded in 221 BC, with elements such as merit-based military leadership, combined with mass conscription, a sophisticated taxation system and a bureaucracy selected on the basis of ability rather than family connections. These traits went on through, to a greater or lesser extent depending on the establishment, all 19 Chinese dynasties up to the last emperor. In modern China, there have been five generations of Chinese leaders and we see a continuity of grand strategies and application of the same principles of Socialism with Chinese Characteristics, inherited from one establishment by the other. But how are leaders made in the People's Republic of China? There are more than 85 million Party members in the Chinese Communist Party (CCP) and in order to qualify for leadership, one has to go through decades of selections which challenge leadership and personal skills.

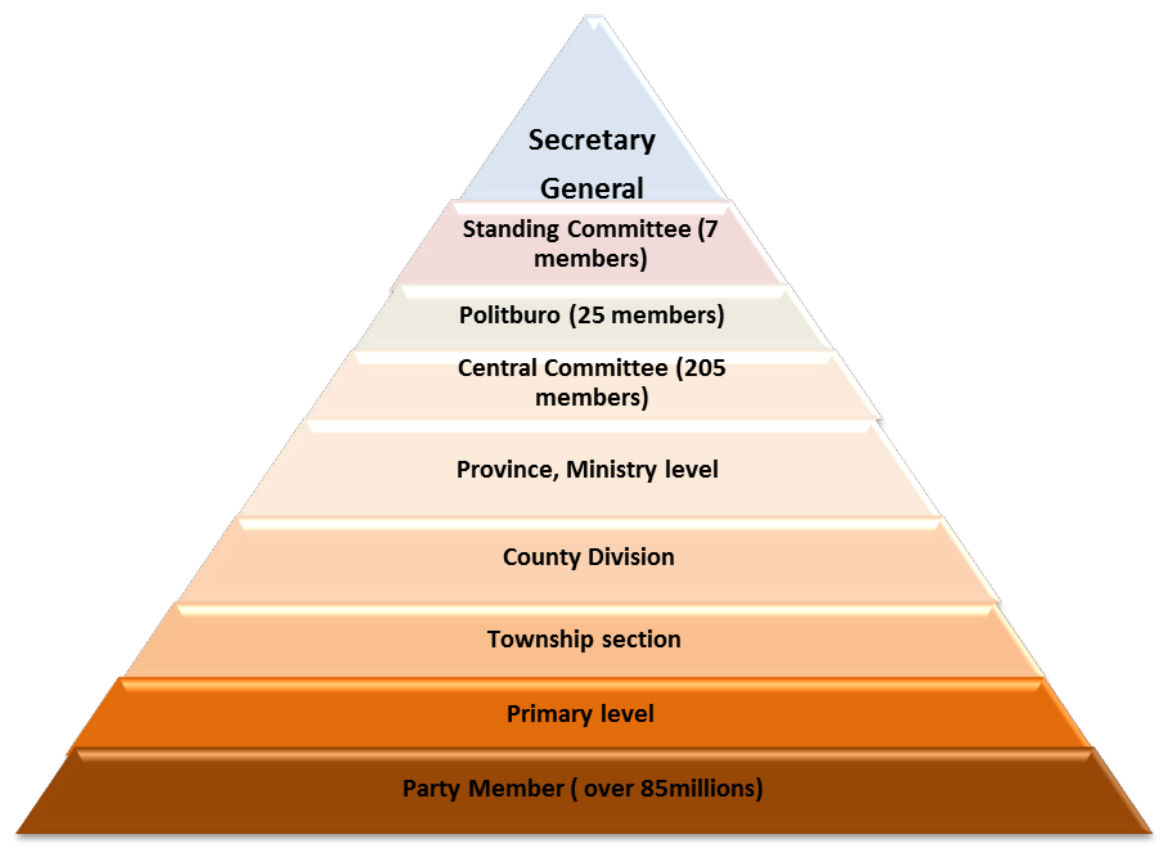

Figure 1. CCP hierarchy, 2017

Starting from the second generation of Chinese leadership (post- Mao era), before the party member could take over the helm of China, he/ 
she would have participated in the deliberation and formulation of many major strategies and policies. That is why over the last decades, through several leadership transitions, China has managed to keep her policies generally consistent and worked along one national development strategy. The current president of China started at a primary-level office, one similar to community councils in the West, later he was promoted to run a county, then a city, and then different provinces like Fujian, Zhejiang and Shanghai, he went on to become the Vice President (VP) and finally the Party General Secretary and the President. He experienced 16 major job-transfers and governed an accumulative population of over $150,000,000$ people over 40 years.

Dean et al. (2013, p. 87) wonder how the CCP regime has managed to remain so unshakeable. And they come to the conclusion that: "[...] the most important aspect of this resilience is the Party's ability to learn, a capacity which allows the regime to adapt to new economic and social conditions...rather than simply borrowing and imitating concepts from abroad, the Party draws out relevant ideas and incorporates its own influences, often creating new concepts which are akin to their Western counterparts in name alone." The CCP's adoption and modification of outside concepts can be seen as a form of "reflexive modernization," in which, after analysis and interpretation of foreign experiences, it is able to pick and choose those concepts which are most useful to its own modernizing aims.

Sorace $(2017$, p. 8) thought it also crucial to understand the CCP composition, he states:

According to the Communist Party's political anatomy, each individual Party member 党员 [Dăngyuán] is a 'cell' 细胞 [Xìbāo] in the 'Party organism' 党的肌体 [Dăng de jītǐl.

In 2016, Xi Jinping's phrase of 'cellular engineering' 细胞工程 [Xìbāo gōngchéng] entered official parlance as an integral component of 'Party Construction' 党的建设 [Dăng de jiànshè] — the idea that the Party is never a completed or static entity but a work-in-progress.

\section{A Smooth Transition to the "Opening up" Stage}

Perhaps one of the least understood economies in the world today is China. For the last 30 years it has grown at an average higher than $10 \%$ per year, has lifted hundreds of millions of people out of poverty and has become the world's second largest economy. However, we must not ap- 
proach China as a typical case of a developing country, of course it has adopted conventional development strategies: urbanization, industrialization, globalization... and these have been instrumental in jump starting China's economic growth. Naughton $(2017$, p. 3) believes that it is important to gain a fresh perspective on the current reality of the Chinese economy. He believes that we should analyze it on the following criteria: "capacity, intention, redistribution, and responsiveness. The objective of China's state intervention has clearly shifted from growth at any price to a more complex set of goals that includes redistribution and social and economic security."

One of the most powerful policy tools that China has, and it will continue to have, is precisely, reform. Reform is China's second revolution said Deng Xiaoping. We should not forget the economic context when China began its economic development in the late 1970s. It was a centrally planned economy and, by definition, distortion ridden. So the process of reform entailed gradual removal of distortions, because unlike the ex-Soviet bloc, China chose to adopt a gradualist reform process towards the market economy, and there are still many distortions left. The gradualistic approach started with the 1980s, when the government decided to try it out. The experimentation started with special economic zones, where only four of which received special industrial policies, welcomed foreign capital, foreign trade and by the mid-1980s these four became fourteen and by the 1990s the coastal cities, which were the first free economic zones, had expanded inland, and studies have shown that introducing Special Economic Zones (SEZ) in a city has increased GDP per capita in $20 \%$ over time.

The 1990 reform was characterized by mass privatization, in particular the privation of State-Owned Enterprises (SOE). So, inefficient entities of SOEs were driven to restructure or completely shut down, they were privatized or formed joint-ventures with foreign companies. In 1992, the Shanghai Stock Exchange reopened for the first time as a test and experimentation, and with the success they had they continued and deepened. In the mid-90s the GDP growth had a slowdown and stagnation, and the answer to that was again, reform. In 1994 China announced a comprehensive economic reform program covering the fiscal and taxation system, central and commercial banking, foreign exchange, trade, investment and enterprise management. The initiative was an important step taken by the government in striving towards a more market-oriented economy with effective macroeconomic control (Shu-Ki 
\& Yuk-Shing 2004, p. 769|. The next wave of reforms in 2000 was increasing globalization, and trade liberalization; in 2001 China joined the World Trade Organization (WTO), at the same time we saw growth pick up and rekindle, it led to a massive amount of foreign currency surplus, trade surplus, and FDIs. So, reform in China is a very powerful tool for the stimulus of growth, unlike any other developing countries. Overholt $(2005$, p. 2) believes that "[...] all of China's economic successes are associated with liberalization and globalization, and each aspect of globalization has brought China further successes. Never in world history have so many workers improved their standards of living so rapidly. China's success is one of the most important developments of modern history. Reformist China does not seek to change the way we organize ourselves or the world, but rather to join the world system we (the west) have created."

Wei et al. $(2017$, p. 49) argue that China's economic growth of the previous three and a half decades was based on several key factors:

a sequence of market-oriented institutional reforms, including openness to international trade and direct investment, combined with low wages and a favorable demographic structure. ... China's rapid growth in the past several decades has been driven by a combination of two sets of factors: a) market-oriented policy reforms to let market - determined output prices and factor prices replace administrative prices, to introduce and strengthen property rights, and to reduce barriers to international trade and investment; and b) economic fundamentals, including in particular a favorable demographic structure and a low initial level of labor cost.

But it does not stop here; in 2014, President Xi Jinping put his legitimacy on the line as to whether he can successfully implement these reforms. Reforms have been long delayed and they are at the forefront of all polices and it is very important to realize that there is a political undertone to his announcement of a new reform package.

\section{Xi Jinping, The Man With a Dream and Plan}

\subsection{The Dream}

Soon after getting to be General Secretary of the Communist Party of China in late 2012, Xi expressed what might turn into the hallmark of his administration. "The Chinese Dream," he said, is "the great rejuvenation of the Chinese nation." Xi's "Chinese Dream" is portrayed as accomplish- 
ing the "Two 100s."1 President Xi's main idea is to restore China's pre-nineteenth century grandeur and influence in order to make it a "prosperous, strong, culturally advanced and harmonious country." Penny (2015, p. 6) highlights that Xi's respect, even reverence, for traditional Chinese cultural traditions (and their usefulness in the present) extends to Chinese literature and philosophy: "he leavens his political essays, speeches and commentaries on contemporary society with quotations in literary Chinese from both pre-modern and ancient texts." Kissinger (2014, p. 221) argues that the rise of China into eminence in the $21^{\text {st }}$ century is not new but it reestablishes historic patterns. What is distinct about it is that China is returned as both the inheritor of an ancient civilization and as a contemporary great power on the Westphalian model. It combines the legacies of all under heaven, technocratic modernization and an unusually turbulent $20^{\text {th }}$ century quest for a synthesis between the two.

In Wang $(2014$, p. 11) we see that the concept of national rejuvenation is deeply rooted in China's national experience and collective memory. Rejuvenation represents the shared desire of Chinese who want their country to be strong, prosperous, and free of foreign invasions, as was previously discussed.

Even though $\mathrm{Xi}$ is the first Chinese leader to promote the "Chinese Dream," the concept of national rejuvenation has been used by many Chinese leaders. Actually, almost every generation of Chinese leaders, from Sun Yet-Sen to Jiang Zemin, to Hu Jintao, has used the national humiliation discourse and the goal of rejuvenation to mobilize the Chinese populace to support their revolution or reform. With Mao Zedong it was lighter since the emphasis for driving the masses was the victory of the Revolution. With Deng in power we saw the phrase "invigorating China" from the early 1980s. In the early 1990s, the Party used the new phrase "the great rejuvenation of the Chinese nation" as the new mission of the party. With $\mathrm{Hu}$ Jintao we see in many of his public speeches a desire to "strive harder for the great rejuvenation of the Chinese nation." The economic growth and fast paced development has made the Chinese leadership under Xi Jinping more confident obviously and the Dream of 2013 focuses on hope and glory, making it more positive and more suitable for Chinese people today.

1 The material objective of China turning into a "respectably well-off society" by 2021, the $100^{\text {th }}$ commemoration of the Chinese Communist Party, and the modernization objective of China turning into a fully developed country by around 2049, the 100th commemoration of the establishing of the People's Republic of China. 
How is this Dream Perceived Internationally? According to Davies (2015, p. 162) Xi Jinping has used a Community of Shared Destiny in two ways. Initially, he evoked the image of a strong and prosperous nation living happily under party rule — the "China Dream." Later, he extended it to describe China's foreign policy.

In his speech of October 25, 2013, in Beijing at the Workshop on Diplomatic Work with Neighboring Countries, Xi highlighted the importance of reassuring the world that "the China Dream will combine with the aspirations of the peoples of neighboring countries for a good life and the hopes of all for regional prosperity so that the idea of a Community of Shared Destiny can take root among our neighbors" (Davies 2015, p. 163).

Sorensen (2015, p. 61) analyzes the "Chinese Dream" from an international relations point of view, through a fold of official releases and concludes that in speeches and statements mentioning the "Chinese Dream," $\mathrm{Xi}$ and other Chinese foreign policy leaders highlight China's peaceful intentions, stronger Chinese international contributions and Chinese aspirations to be a responsible and constructive power in the international system. The main points to take away from Xi's and other Chinese foreign policy leaders' speeches and statements on the "Chinese Dream" as they relate it to developments in China's international role and foreign policy strategy are, firstly, that China under $\mathrm{Xi}$ aims to take on more international responsibilities, but also to "shape" the international system to a higher degree and increasingly present Chinese ideas and solutions to international conflicts and crises. Secondly, that China wants respect and to be treated on an equal footing, and, thirdly, that China will never compromise on China's sovereignty and core interests.

\subsection{The Plan - Belt and Road Initiative (BRI)}

The first time the world heard about this initiative was in Kazakhstan, 2013, during a visit of President Xi to the country. He stated:

Shaanxi, my home province is the starting point of the Silk Road. As I stand here I reflect on history, I can almost hear the camel bells echoing among the mountains and see the wisp of smoke rising from the desert. It all reminds me of home... throughout the millennia, the peoples of various countries along the Silk Road have jointly reached a chapter of friendship that has been passed on this very day...2

2 President Xi chose a foreign neighbor country to launch his idea of the new initiative in the most exclusive academic environment of Kazakhstan: Nazarbayev University, in Astana. 
From the above we can see that this initiative is a tool of a foreign policy master plan as much as it is a personal involvement and challenge for the Chinese number one policy maker. It starts with evoking the past, while tracing the guidelines for the future cooperation of the countries involved in the initiative. From that year on, with the shift of power in Chinese leadership we see a very proactive attitude in foreign affairs.

The Belt and Road Initiative proclaimed by President Xi in 2013, is a strategy developed by the Chinese government, it has a Chinese content to it, it is very important to China but it should not be confined to China. In order for it to be successful it needs to be embraced by the countries on the terrestrial and maritime route indicated in the plan. This Initiative is trying to revitalize the ancient Silk Road trading routes by connecting East and West over land and sea. For over 1600 years the Silk Road promoted the exchange of Western and Eastern civilizations, bringing together Chinese, Indians, Persians, Arabs, Greeks and Romans. The proposed revival of a great trade route which two thousand years ago bridged Eastern and Western cultures across the Eurasian continent might well help realize that objective. It is President Xi's vital arrangement to associate Asia and Europe by putting resources into framework activities to improve exchange and social relations, upheld by unfathomable money related assets, including a US $\$ 40$ billion Silk Road Fund, the US $\$ 100$ billion AIIB fund, and the US\$50 billion New Development Bank (NDB). What is happening today with Chinese foreign policy is that Beijing functionaries are trying to inject new vitality into the ancient trading routes through a new economic master plan that could connect Asia, Europe and Africa with one single development policy, financially supported by the Chinese Government. It promotes practical cooperation in all fields and works to build a community of shared interests, destiny and responsibility featuring mutual political trust, economic integration and cultural inclusiveness.

Ferdinand (2016, p. 75) argues:

[...] the hopes for the impact of the 'one belt, one road' initiative are grandiose, and if it is realized in full, it will indeed fundamentally transform the geography of global affairs, though the time-scale over which this is envisaged as taking place is a long one. ... But the Belt and Road Initiative also rests upon a hope, indeed an assumption, that all of the many projected partners will respond with corresponding enthusiasm, because without their active cooperation the project will fail to live up to Chinese expectations. 
The latest significant event promoting the Initiative was the Belt and Road Forum held in May 2017; one of the major announcements from the BRF was Xi's pledge to further boost funding for the project. In his keynote, Xi promised China will funnel an additional RMB 100 billion (\$14.5 billion) into the Silk Road Fund, while the China Development Bank and Export-Import Bank will set up new lending schemes of 250 billion (\$36.2 billion) and RMB 130 billion (\$18.8 billion), respectively, for Belt and Road projects. In addition, China will provide RMB 60 billion (\$8.7 billion) for humanitarian efforts focused on food, housing, health care, and poverty alleviation.

\subsection{How the BRI could affect the current and future state of international affairs}

In order for the Belt and Road Initiative to unfold its potential, an estimation of at least 35-40 years will be required ( $\mathrm{Li}, 2014)$, hence, it is very early to have any kind assessment of the advantages and disadvantages. Nonetheless, we see in academia and in practitioners many predictions on how and when this initiative will "fully" reveal itself. This diversity of views about the implications of China's rise in global politics is testimony to the uncertainty associated with that rise. But one aspect is abiding: As Shambaugh (2013, p. 317) states:

[...] China going global will undoubtedly be the most significant development in international relations in the years ahead. Since China's opening to the world in 1978, the world has changed China - and now China is beginning to change the world.

The BRI is the most recent blueprint of China going global. Regarding Europe, with EU countries the final destination of the modern Silk Road, European interests, involvement and perceptions are crucial to how the BRI is projected outside China. Beijing has had to adjust its European policies to take into account both Union and country-level decision-making procedures, further complicated by the lack of single cohesive EU foreign and often economic policy (Lanteigne 2013, p. 144).

From one side of the spectrum, we see concern and suspicious attitudes towards the BRI (Mohan, 2018; Prasad, 2018; Chi, 2015; Sárvári \& Szeidovitz, 2018; Callahan, 2016; de Jong et al. 2017; Casarini; 2015) with possible threats involving the national security of EU countries, the 
possible undermining of internal cohesion, dumping or exporting goods priced below production costs, thus risking destroying entire industrial lines across Europe; for this and more there is a need for Europe to increase its resilience.

On the other side, the arguments displayed are more optimistic with no alarmist notes (Wang, 2016; Fasslabend, 2015; Yilmaz, \& Changing, 2016; Godement, 2017; Overholt, 2015; Liu, 2017; Huang, 2017); these experts emphasize that China's BRI should not be viewed as a threat but as an opportunity, that the EU should be enthusiastic about the project and not hesitant since it is designed to connect China and Europe through inclusive development of all participating nations; since BRI is focused on infrastructure projects and connectivity it should be in line with conventional wisdom that a deeper network of road, railroads, maritime routes and corridors will bring prosperity to all parties involved.

Many seem concerned about what is not proclaimed in the plan; which is the final aim of this terrestrial expansion throughout the Belt and Road countries. What the skeptics fail to admit is that securing economic growth is at the core of national security policy proclaimed from Beijing and to further ease worries President Xi has emphasized the "Three No's" policy within the BRI. ${ }^{3}$

China with the BRI wants to join the world system with the rules that western powers have created and enhance cycles of development and wealth along the route for the benefit of all.

\section{Conclusion}

In his book "The Governance of China", President Xi uses the word Dream 528 times; this alone can provide an explanation of the major attention and the importance associated with the "Chinese Dream" proclaimed by the number one policymaker in the People's Republic of China. He is not the first to speak out about the "Chinese Dream" but differently from his predecessors, $\mathrm{Xi}$ is ruling at a time when China's position in the international arena is stronger than ever, coming to be the second largest economy in the world. In his own words: "Why are we so confident? Be-

3 China will not interfere in the internal affairs of the nations along the BRI route; will not try to increase its influence on these nations; PRC is not striving for hegemony or dominance. 
cause we have developed and become stronger. China has won worldwide respect with its century-long efforts. Its prestige keeps rising, and its influence keeps expanding." 4

Over the last decades, through several leadership transitions, China has managed to keep her policies generally consistent and worked along one national development strategy. The "Chinese Dream" might have had different labels in the past but it was always present in concept and intentions throughout every establishment. This Dream has two major implications: inwards and outwards; the inward, meaning inside the PRC, the Dream evokes the glorious past of the Middle Kingdom while trying to implement it in the $21^{\text {st }}$ century, and calls for the achievement of personal dreams of Chinese people throughout the realization of the nation's dream. ${ }^{5}$ It becomes attractive to its citizens since in these years there is the general feeling of achieving that goal, as Yan Xuetong puts it: "In 1978, China dream was set into motion. Xi Jinping is not the first one to talk about 'The national rejuvenation' but is talking about the possibility to achieve it within our lives." The outward intentions of the "Chinese Dream" are better crystallised with the Belt and Road Intiative. So, it's not a Dream any longer, it's a plan! China going global will undoubtedly be the most significant development in international relations in the years ahead. Since China's opening to the world in 1978, the world has changed China - and now China is beginning to change the world! The proposed revival of the ancient Silk route which two thousand years ago bridged Eastern and Western cultures across the Eurasian landmark might help realize that objective. Billions of dollars have been targeted toward neighboring countries, Europe and Africa, through means of enormous infrastructure projects and soft loans for developing countries.

And while China stands to reap major benefits from BRI projects, it is also footing a significant proportion of risk entailed with this project, since many countries targeted by the BRI are prone to economic and political instability.

4 May 4, 2014 - Speech at the seminar with teachers and students of Peking University.

5 Indeed, when Xi (2013, pp. 3-4) introduced his China dream in November 2012, he stressed how the country and the nation have to come first: "History tells us, the destiny of each person is closely connected to the destiny of the country and of the nation. Only when the country does well, and the nation does well, can every person do well." 


\section{References}

Callahan, W.A. 2015, "Identity and security in China: the negative soft power of the China dream," Politics, vol. 35, no. 3-4, pp. 216-229.

Davies, G. 2015, "Destiny's Mixed Metaphors," in: Barmé G., Jaivin, L., \& Goldkorn J. (eds.), Shared Destiny, ANU Press, pp. 150-171.

Ferdinand, P. 2016, "Westward ho-the China Dream and 'one belt, one road': Chinese foreign policy under Xi Jinping," International Affairs, vol. 92, no. 4, pp. 941-957.

Fukuyama, F. 2013. "Professor Francis Fukuyama: Qin Dynasty China Is the First Modern State in History," Beijing University, Office of International Relations, Speech 14/03/2013. Available at http://www.oir.pku.edu.cn/En/html/2013/Voice_0314/82. html.

He, K. and Feng, H. 2013, "Xi Jinping's operational code beliefs and China's foreign policy," The Chinese Journal of International Politics, vol. 6, no. 3, pp. 209-231.

Kissinger, H. 2014, World Order: Reflections on the Character of Nations and the Course of History, London, Penguin.

Miller, A. 2014, "How Strong is Xi Jinping?," China Leadership Monitor, vol. 43, pp. 1-2.

Murphy Tsai, W. and Dean, N. 2013, "The CCP's Learning System: Thought Unification and Regime Adaptation," The China Journal, vol. 69, pp. 87-107.

Musabelliu, M. 2017, "China's Belt and Road Initiative Extension to Central and Eastern European Countries-Sixteen Nations, Five Summits, Many Challenges," Croatian International Relations Review, vol. 23, no. 78, pp. 57-76.

Naughton, B. 2017, "Is China Socialist?," The Journal of Economic Perspectives, vol. 31, no. 1 , pp. 3-24.

Overholt, W. 2005, China and globalization, RAND.

Penny, B. 2015, "Classic XI Jinping: On Acquiring Moral Character," in: Barmé G., Jaivin L., \& Goldkorn J. (eds.), Shared Destiny, ANU Press, pp. 4-13.

Sorace, C. 2017, "Communist Party Immunology," in: Golley J., Jaivin L., \& Tomba L. (eds.), Control, ANU Press, pp. 99-108.

Sørensen, C. 2015, “The Significance of Xi Jinping's 'Chinese Dream' for Chinese Foreign Policy: From 'Tao Guang Yang Hui' to 'Fen Fa You Wei'," Journal of China and International Relations, vol. 3, no. 1, pp. 53-73.

Shambaugh, D. 2001, "The dynamics of elite politics during the Jiang era," The China Journal, vol. 45, pp. 101-111.

Shu-Ki, T. and Yuk-Shing, C. 1994, "China's tax reforms of 1994: breakthrough or compromise?" Asian Survey, vol. 34, no. 9, pp. 769-788.

Vogel, E.F. 2011, "Deng Xiaoping and the transformation of China," vol. 10, Cambridge, MA: Belknap Press of Harvard University Press.

Wang, Z. 2014, "The Chinese dream: concept and context," Journal of Chinese Political Science, vol. 19, no. 1, pp. 1-13.

Wei, S., Xie, \& Zhang, X. 2017, "From 'Made in China' to 'Innovated in China': Necessity, Prospect, and Challenges," The Journal of Economic Perspectives, vol. 31, no. 1, pp. 49-70.

Wielander, G. 2017, "Chinese Dreams of Happiness: What Are the Chances?," in: Franceschini I., Lin K., \& Loubere N. (eds.), Disturbances in Heaven, ANU Press, pp. 136-141.

Xi, J. 2014, The governance of China, Foreign Languages Press.

Zheng, Y. and Tok, S.K. 2007, "Harmonious society and harmonious world: China's policy discourse under Hu Jintao," Briefing Series, no. 26. 